\title{
Mental health care system and reform efforts in Ukraine
}

\author{
Vitalii Klymchuk $^{1}$, Kateryna Kalendruz ${ }^{2}$, Viktoriia Gorbunova ${ }^{3}$ \\ ${ }^{1}$ Institute of Social and Political Psychology, Kiev, Ukraine \\ ${ }^{2}$ World Health Organisation, Kiev, Ukraine \\ ${ }^{3}$ Mental Health. Solution, Zhitomir, Ukraine
}

\begin{abstract}
Introduction. Currently, Ukraine has a centralized mental health (MH) system, mainly concentrated in large psychiatric hospitals, located in big cities, with a lack of services in rural areas. The quality of services delivered by the psychiatric facilities is low.

The conflict in the East has produced new challenges. On one hand, it activated civil society and international organisations to provide psychosocial support for IDPs, host communities and veterans. On the other hand, it revealed the government incapacity to organise its services.

Nowadays there is a consensus that MH services are best provided in local settings. The community-centred approach is manifested in the World Health Organization Mental Health Action Plan 2013-2020 (World Health Organization, 2013).

Purpose. The abstract purpose is identifying the key goals of the Ukrainian MH transformation efforts according to the national legislation and the WHO trends.
\end{abstract}

Methodology. The methodology of our study includes the review of Ukrainian legislation against the background of the Convention WHO Mental Health Action Plan 2013-2020 (possibilities, limitations, and region specific) as a base for formulating the key goals of the Ukrainian $\mathrm{MH}$ transformation efforts.

Results. Ukrainian national policy documents (Mental Health Care Development Concept Note in Ukraine for the period of up to 2030 adopted in 2017 (Cabinet of Ministers of Ukraine, 2017) and Mental Health Action Plan for the period of up to 2030, which is in the process of being approved) outline the government's plans to improve $\mathrm{MH}$ service provision by decentralizing the system, supporting the development of community-based MH services, enhancing the skills of PHC professionals, and introducing a certification system for $\mathrm{MH}$ professionals.

The law on autonomy of medical facilities, adopted in April 2017 (Parliament of Ukraine, 2017a), the new healthcare financing law adopted in October 2017 (Parliament of Ukraine, 2017b), and many other decrees of the Ministry of Health and the Cabinet of Ministers of Ukraine are meant to give the medical facilities freedom to make their own choices when it comes to staffing, financing and type of services provided.

There is a large number of MH players in Ukraine. They range from newly established in February of 2018 Center for Mental Health and Drug and Alcohol Monitoring of the Ministry of Health, to non-governmental organizations, such as Ukrainian Institute of Cognitive-Behavioural Therapy, Ukrainian Psychiatric Association, National Psychological Association, and others.

There are two key goals of the MH transformation efforts according to the National Concept Note and Mental Health Action Plan for the period of up to 2030.

Goal 1: Improving the framework conditions for the mental healthcare system. The MH legal and regulatory framework requires improvement in the directions of respect for human rights (especially in terms of gender, age, ethnicity or socioeconomic groups) and creation of the enabling environment for the decentralization of services, developing clear regulations for the MH facilities and quality assurance mechanisms. This should be 
in line with strengthening MH advocacy efforts, policy dialogue and data-informed policy making. $\mathrm{MH}$ workforce capacities and skills need strengthening through introducing new certification, accreditation and licensing mechanisms and setting evidence-based standards of treatment, development of new training curricula, improving quality of education and improvement of the capacities and skills of primary care and MH professionals.

Goal 2: Development and strengthening of the community-based care, prevention and destigmatization. Community-based model of care should be developed through using the deliverables from the Goal 1 and building the local optimal mix of services, starting from the self-care and prevention/promotion programs, through development of the primary care and community-based MH care models and improving accessibility (in addition to fighting stigma) plus referral network. Primarily focus should be the accessibility of $\mathrm{MH}$ services at all levels of healthcare (community, primary, secondary, tertiary healthcare and medical rehabilitation) with special attention to the population at risk of discrimination (by gender, ethnicity, age or socioeconomic status). Capacities of society to provide prevention/promotion, fight stigmatization and discrimination may be strengthened through a range of activities aiming towards promoting mental health and human rights in medical facilities, educational institutions, workplace. Within this goal, an important aspect is delivering evidence-based care to conflict-affected population.

Limitations of the study. The limitation of the study is reliance on ongoing legislation and current situation, that can change with the policy changes of the government.

Social value. Improving the MH framework conditions and development of the community-based care models in Ukraine might push up the quality of care for people with mental health disorders not only in terms of health treatment but also as a care about human rights, gender issues, and daily wellbeing.

Conclusions. Currently, there is full governmental support and active position of the Ministry of Health of Ukraine in the reform efforts in the area of mental health services in Ukraine. There are Mental Health Care Development Concept Note and Mental Health Action Plan. The key goals of the MH transformation efforts are improving the framework conditions for the mental health care system, standardising the workforce education through professional licensing, development of the community-based care models, placing emphasis on prevention and destigmatisation.

\section{References}

World Health Organization. (2013). Mental health action plan 2013 - 2020. Geneva: WHO.

Parliament of Ukraine (2017a, April 6). Pro vnesennia zmin do deiakykh zakonodavchykh aktiv Ukrainy shchodo udoskonalennia zakonodavstva z pytan diialnosti zakladiv okhorony zdorovia [On Amending in Certain Legislative Acts of Ukraine to Improving Legislation on Activities of Health Care Institutions]. Retrieved from http://zakon2.rada.gov.ua/laws/show/2002-19

Parliament of Ukraine (2017b, October 19). Pro derzhavni finansovi harantii medychnoho obsluhovuvannia naselennia [On State Financial Guarantees of Public Health Care]. Retrieved from http://zakon2.rada.gov.ua/laws/show/2168-19

Cabinet of Ministers of Ukraine (2017, December 27). Kontseptsiia rozvytku okhorony psykhichnoho zdorovia v Ukraini na period do 2030 roku [Mental Health Care Development Concept Note in Ukraine for the period of up to 2030]. Retrieved from http://zakon3.rada.gov.ua/laws/show/1018-2017$\% \mathrm{D} 1 \% 80$ 
Keywords. Ukraine, mental health, services, health care system, community facilities, psychiatry, psychology. 